\title{
DAMPAK IMPLEMENTASI ERP DALAM PERBAIKAN SISTEM DISTRIBUSI PADA PT SEMEN GRESIK
}

\author{
I Gusti Made Karmawan \\ Computerized Accounting Department, School of Information Systems, Binus University \\ Jl. K.H. Syahdan No. 9, Palmerah, Jakarta Barat 11480 \\ sudida@binus.edu
}

\begin{abstract}
This study describes how to implement an ERP system at PT Semen Gresik and compares the positive and negative effects of the implementation in the distribution process improvement. The benefits that can be obtained from this paper is obtaining information of how to implement an ERP system and the positive and negative effects of ERP implementation at PT Semen Gresik in the distribution process improvement. This study was done through documentation review to obtain the description of distribution process in the inventory material planning at PT Semen Gresik. The study resulted in a comparison between the positive and negative aspects as an effect from ERP implementation process at PT Semen Gresik in distribution process improvement. The ERP implementation process at PT Semen Gresik does not only provide more efficiency and effectiveness of distribution system, but also consequences of the impact from the effectiveness and efficiency obtained.
\end{abstract}

Keywords: ERP, Distribution Systems, efficiency and effectiveness

\begin{abstract}
ABSTRAK
Penelitian ini memaparkan bagaimana ERP diimplementasikan pada PT Semen Gresik dan membandingkan dampak positif dan negatif dari implementasi tersebut dalam perbaikan proses distribusi. Manfaat yang ingin diperoleh yaitu mendapatkan pemahaman mengenai pengimplementasian ERP dan mengetahui dampak positif dan negatif implementasi ERP pada PT Semen gresik dalam perbaikan sistem distribusi. Metode penelitian menggunakan review dokumentasi untuk memperoleh gambaran atas proses distribusi dalam perencanaan material inventory PT Semen Gresik. Hasil yang dicapai adalah mendapatkan perbandingan antara dampak positif dan negatif akibat implementasi ERP pada PT Semen Gresik dalam perbaikan proses distribusi. Implementasi ERP pada PT Semen Gresik memberikan dampak yang baik bagi efektivitas dan efisiensi pada proses perbaikan sistem distribusi, tapi juga memberikan konsekuensi atas dampak efektivitas dan efisiensi yang diperoleh.
\end{abstract}

Kata kunci: ERP, sistem distribusi, semen gresik 


\section{PENDAHULUAN}

Enterprise resource planning (ERP) adalah suatu sistem yang membantu untuk yang mengatur proses distribusi seperti marketing, produksi, pembelian dan accounting dalam suatu kesatuan yang terintegrasi (Brady, et al., 2001). Konsep terpenting dari sistem ERP adalah integrasi, yaitu menggabungkan berbagai kebutuhan pada satu software dalam satu logical database, sehingga memudahkan semua departemen berbagi informasi dan berkomunikasi.

Masalah yang sulit bagi perusahaan yang mengimplementasikan sistem ERP adalah mengintegrasikan sistem yang terpisah-pisah di perusahaan, berpindah area fungsional yang terpisah menjadi sebuah sistem komputer yang dapat melayani kebutuhan antar departemen yang berbeda.

Dalam konteks ERP, Fiona Fui-Hoon Nah, et al. (2004) mendefinisikan perceived fit dari sudut pandang user, sebagai persepsi seseorang bahwa sistem SAP yang digunakan sesuai dengan proses bisnis perusahaan. Perceived compatibility sebagai persepsi seseorang bahwa sistem SAP yang digunakan konsisten dengan cara bekerja yang diinginkan/disukai, dan pengalaman bekerja. Shared belief in the benefit of ERP system didefinisikan sebagai tingkat kepercayaan terhadap benefit dari implementasi SAP bagi semua level di organisasi. (Diadaptasi dari Gyampah dan Salam, 2004). Facilitating condition didefinisikan sebagai pendapat seseorang bahwa sistem SAP dapat digunakan jika organisasi memberikan kondisi yang dapat memfasilitasi penggunaan/pengoperasian sistem SAP

PT Semen Gresik bergerak di industri semen dan memiliki distributor yang tersebar di berbagai daerah di Indonesia. Sistem distribusi semen dari pabrik Tuban ke distributor di Jawa Barat pada PT Semen Gresik dimulai dari proses produksi semen di Tuban. Setelah itu semen hasil produksi pabrik Tuban dikemas dan dikirim ke gudang penyangga di Jawa Barat. Kemudian dari gudang penyangga di Jawa Barat semen akan dikirim ke distributor-distributor yang tersebar di berbagai daerah di Indonesia.

Sebelumnya gudang penyangga PT Semen Gresik beroperasi tanpa mengintegrasikan sistem informasinya. Kesalahan penempatan (assignment) gudang penyangga pada tiap fasilitas dalam sistem dapat menyebabkan inefisiensi pada sistem distibusi. Oleh karena itu, memperbaiki kinerja dalam pendistribusian produk ini merupakan salah satu jalan yang harus ditempuh.

Dalam hal ini, PT Semen Gresik dapat mengimplementasikan teknologi enterprise resources planning (ERP). Melalui ERP, fungsi-fungsi bisnis dalam PT Semen Gresik yang masih terdiri dari aktivitas-aktivitas yang individual dengan lokasi kerja yang terpisah satu dengan yang lain dapat diintegrasikan secara real time. Dengan demikian, waktu yang dibutuhkan untuk mengkoordinasikan data antara fungsi bisnis dapat menjadi lebih singkat (efisiensi), karena kemungkinan terjadinya kesalahpahaman dalam mengkomunikasikan data antar lokasi kerja dapat dikurangi. Data dan seluruh informasi dapat diintegrasikan ke pusat penyimpanan data sehingga dapat dengan mudah diakses oleh user yang membutuhkan. Sehingga, PT Semen Gresik dapat dengan meningkatkan efisiensi pengelolaan sistem informasi, menyederhanakan dan mengintegrasikan proses distribusi serta dapat memperbaiki pengambilan keputusan oleh manajemen.

Sistem ini merupakan hal yang sangat diinginkan bagi pemilik perusahaan termasuk berbagai bagian yang terlibat serta para customer. Oleh sebab itu, sistem distribusi diharapkan dapat menjadi jawaban utama atas masalah-masalah yang sedang dihadapi oleh perusahaan.

Ruang lingkup penelitian ini adalah: (1) membahas pertimbangan dalam perbaikan sistem distribusi dengan implementasi ERP pada PT Semen Gresik; (2) membahas prosedur implementasi ERP pada PT Semen Gresik; (3) membahas cara kerja ERP dalam perbaikan sistem distribusi PT 
Semen Gresik; (4) membahas hasil implementasi ERP pada PT Semen Gresik dalam perbaikan sistem distribusi.

Tujuan yang ingin dicapai antara lain: (1) memaparkan bagaimana ERP di implementasikan untuk mendukung sistem distribusi pada PT Semen Gresik; (2) membandingkan dampak positif dan negatif implementasi ERP pada PT Semen Gresik di dalam menjalankan proses distribusi.

Manfaat yang dapat diperoleh dari penelitian ini antara lain: (1) mendapatkan pemahaman mengenai pengimplementasian ERP pada PT Semen Gresik; (2) mengetahui hasil implementasi ERP pada PT Semen Gresik dalam perbaikan sistem distribusi; (3) mengetahui dampak positif dan negatif implementasi ERP pada PT Semen Gresik dalam perbaikan sistem distribusi.

\section{METODE}

Berbagai data yang digunakan dalam menyusun karya ilmiah ini ialah data yang diperoleh dari beberapa sumber yang berbeda tapi sesuai dengan fakta yang ada sekarang ini, seperti halnya mengenai keberadaan, cara kerja ERP. Data data tersebut kami peroleh dari beberapa sumber, yaitu buku-buku referensi, dan dari website. Data yang diperoleh merupakan data sekunder. Teknik yang digunakan selanjutnya ialah observasi yaitu pengumpulan data dengan cara pengamatan langsung terhadap berbagai macam kinerja yang terjadi pada Sistem Distribusi pada PT Semen Gresik.

\section{HASIL DAN PEMBAHASAN}

\section{Pertimbangan dalam Perbaikan Sistem Distribusi dengan Implementasi ERP pada PT Semen Gresik}

Kesadaran akan perlunya sistem yang terintegrasi direalisasikan oleh PT Semen Gresik dengan memulai pengimplementasian ERP pada tahun 2001 silam guna mendukung efisiensi proses distribusi yang ada di PT Semen Gresik. Berikut ini dipaparkan secara singkat hal-hal yang mendorong PT Semen Gresik untuk mengimplementasikan ERP, yaitu: (1) kebutuhan untuk melakukan perbaikan proses distribusi karena adanya kesalahan penempatan (assignment) distributor pada tiap fasilitas dalam sistem dapat menyebabkan inefisiensi pada sistem distibusi; (2) keinginan melakukan standarisasi proses distribusi dengan sistem informasi agar dapat mendukung seluruh kegiatan distribusi; (3) kebutuhan akan pondasi sistem informasi yang kuat dan mampu memberikan informasi yang relevan dan real time; (4) perlunya sistem informasi yang terintegrasi guna mengoptimalkan kinerja perusahaan di dalam jaringan distribusi dan jaringan pengiriman yang tersebar luas di berbagai daerah; (5) perlunya sistem yang tersentralisasi agar pengiriman pesanan antara distributor dapat diproses dan dipenuhi sesegera mungkin; (6) penggunaan aplikasi berbasis program Foxbase dan database Sybase sebelumnya tidak begitu efektif untuk menunjang kinerja distribusi perusahaan dan fungsi-fungsi bisnis yang ada di perusahaan belum terintegrasi; (7) kebutuhan informasi yang diperlukan oleh user dalam PT Semen Gresik terus berkembangan, tidak lagi hanya sebatas informasi dari fungsi bisnisnya sendiri, tapi juga dari fungsi bisnis yang lain.

\section{Prosedur Implementasi ERP pada PT Semen Gresik}

Mengimplementasikan ERP bukanlah merupakan suatu hal yang mudah untuk dilakukan. Apalagi untuk perusahaan besar seperti PT Semen Gresik karena ERP memiliki ruang lingkup yang luas dalam suatu organisasi. Jadi, semakin besar perusahaan yang mengimplementasikan ERP, ruang 
lingkup ERP akan semakin luas dan kompleks. Untuk itulah di dalam mengimplementasikan ERP pada perusahaan, PT Semen Gresik perlu membuat perencanaan yang baik.

Berikut adalah urutan prosedur implementasi ERP yang dilakukan PT Semen Gresik:

\section{Membentuk Tim Penanggung Jawab}

PT Semen Gresik memutuskan untuk melakukan pembentukan tim yang bertanggungjawab dalam menetukan ruang lingkup dari pengimplementasian ERP. Tim yang dibentuk ini bernama Tim Sistem Informasi Grup Semen Gresik, tim ini terdiri dari tujuh orang anggota yang terdiri dari tiga orang dari Semen Gresik, dua orang dari Semen Padang, dan dua orang dari Semen Tonasa.

Setelah dibentuk, tim melakukan beberapa kegiatan. Pertama adalah global scopping yang bertujuan untuk menentukan modul-modul yang tepat untuk diimplementasikan pada PT Semen Gresik. Proses ini membutuhkan waktu selama tiga bulan dengan dibantu oleh PriceWaterhouse sebagai konsultan pendamping. Selanjutnya tim melakukan pengkajian terhadap sistem informasi yang tepat untuk perusahaan secara mendalam. Hal ini dilakukan agar dapat memenuhi keinginan manajemen atas sistem informasi yang mampu menunjang aspek operasional, taktis hingga strategis, mampu menciptakan kemudahan, kecepatan dan kenyamanan bagi stakeholder PT Semen Gresik seperti departemen, pemasok, pelanggan dan stakeholder lainnya.

\section{Membentuk Tim proyek Sistem Informasi}

PT Semen Gresik membentuk Tim Proyek Sistem Informasi Grup Semen Gresik sebagai tindak lanjut dari keputusan-keputusan yang ditentukan oleh Tim Sistem Informasi Grup Semen Gresik.

Berikut beberapa tugas yang dilakukan oleh Tim Proyek Sistem Informasi Grup Semen Gresik, antara lain: (1) menentukan definisi atas perencanaan proyek yang sesuai dengan kondisi PT Semen Gresik dan karena PT Semen Gresik akan megimplementasikan ERP maka akan terjadi perubahan proses bisnis. Sehingga perubahan proses bisnis yang dilakukan harus sesuai dengan tujuan perusahaan; (2) melakukan pelaksanaan atas tahap-tahap pengembangan dan penerapan sistem yang diperlukan dengan sebaik mungkin agar dapat memnuhi dengan target waktu yang telah ditetapkan; (3) memberikan usul atas konsultan yang akan ditunjuk dan menetapkan platform sistem informasi yang tepat untuk implementasi ERP pada PT Semen Gresik; (4) membuat susunan perencanaan anggaran mengenai jumlah yang akan dibutuhkan untuk dan melaporkan realisasi biaya proyek yang dihabiskan; (5) melaksanakan pengadaan barang dan jasa dalam batas-batas tertentu yang ditetapkan oleh direksi; (6) membuat laporan bagi manajemen secara berkala dan melakukan dokumentasi proyek.

Kegiatan-kegiatan di atas membutuhkan waktu selama 1,5 tahun, dan PT Semen Gresik memutuskan penggunaan solusi ERP JP Edwards. Pertimbangan ini didasarkan pada keinginan PT Semen Gresik untuk melakukan standarisasi berdasarkan best practise yang telah dilakukan oleh industri lain dan juga berdasarkan pada pengalaman perusahaan-perusahaan semen dunia.

\section{Melakukan Stakeholder Analysis}

Tim Proyek Sistem Informasi Grup Semen Gresik melakukan stakeholder analysis yang merupakan penelitian mendalam terhadap calon user. Analisis membutuhkan waktu selama hampir empat bulan. Tujuan analisis ini adalah untuk mengetahui bagaimana tanggapan dan apresiasi mereka terhadap sistem baru yaitu ERP yang akan segera diimplementasi. Dari analisis tersebut terdapat beberapa calon user di sejumlah departemen menunjukkan tanggapan resistensi terhadap perubahan sistem informasi PT Semen Gresik. 


\section{Membeli Hardware dan Membangun LAN/WAN}

PT Semen Gresik melakukan pembelian hardware untuk mendukung implementasi ERP, yang terdiri dari: IBM Risc 6000 sebanyak dua unit merupakan database yang digunakan sebagai Enterprise Server (database server); IBM Risc 6000 tipe F80 sebagai web server; server Compaq tipe FL 530 untuk deployment server; server IBM RS 6000 F200 sebagai Enterprises Storage Server dan 500 unit PC. Selah melakukan pembelian hardware, PT Semen Gresik membangun jaringan LAN/WAN ke seluruh cabang PT Semen Gresik hingga ke gudang-gudang yang tersebar di beberapa lokasi yang membutuhkan waktu hingga dua tahun.

\section{Melakukan Sosialisasi terhadap User}

PT Semen Gresik melakukan proses sosialisasi terhadap user yang nantinya akan berinteraksi dengan sistem baru yaitu ERP. Adapun kegiatan sosialisasi yang dilakukan PT Semen Gresik antara lain, mengumpulkan seluruh distributor PT Semen Gresik untuk memberikan pengenalan dan pelatihan kepada seluruh distributor mereka.

\section{Mengimplementasikan Modul-modul ERP}

PT Semen Gresik melakukan implementasi terhadap modul-modul ERP dengan dibantu oleh konsultan Berca HardayaPerkasa dan Praweda. Modul yang diimplementasikan meliputi modul Maintenance, Inventory, Purchasing, Finance, Sales Order and Transprotation. Berikut urutan implementasi yang dilakukan pada PT Semen Gresik secara bertahap atas pertimbangan efktivitas, yaitu:

November 2000 : PT Semen Gresik mengimplementasikan modul Maintenance, Inventory dan Purchasing. Modul ini dapat dijalankan, tepatnya pada bulan Oktober 2001.

Januari 2002 : PT Semen Gresik mengimplementasikan modul Finance.

Juli 2002 : PT Semen Gresik mengimplementasikan modul Sales Order and Transportation

\section{Cara Kerja ERP dalam Perbaikan Sistem Distribusi PT Semen Gresik}

Untuk melakukan perbaikan terhadap sistem distribusi, Tim IT Grup Semen Gresik melakukan tahap internalisasi pada distributor di tiap daerah untuk menghubungkan distributor di berbagai lokasi dengan PT Semen Gresik dalam memperbaiki kesalahan penempatan (assignment) distributor pada tiap fasilitas dalam sistem agar dapat menghasilkan efisiensi. Hal yang perlu diperhatikan Tim IT Grup Semen Gresik untuk memfasilitasi distributor adalah leased line dan PC bermodem.

\section{Leased line}

Leased line menggunakan teknologi VSAT (Gambar 1), frame relay, maupun dial up. Sementara, database ERP tersentralisasi di Gresik dapat diakses oleh gudang penyangga di daerah Jawa Bara, Jawa Tengah, D.I Yogyakarta, dan Bali, yang membutuhkan informasi secara real time. Guna menjamin tingkat ketersediaan akses yang tinggi, disediakan redundant server dan jaringan khusus untuk proses-proses tertentu.

VSAT memiliki kemampuan untuk menerima maupun mengirimkan sinyal melalui satelit kepada VSAT lain pada jaringan tersebut. VSAT dapat mendukung kebutuhan komunikasi apapun, baik berupa suara, data, ataupun konferensi video. 


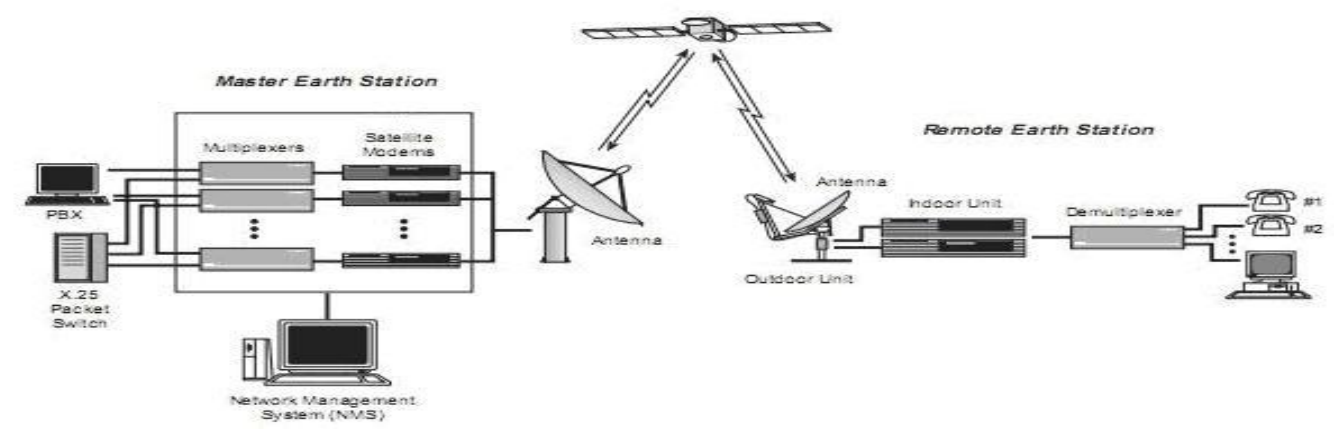

Gambar 1 Arsitektur jaringan VSAT

\section{PC Bermodem}

Dengan menggunakan PC bermodem, mereka tinggal melakukan dial-up ke fasilitas komputer di gudang Semen Gresik yang tersebar di dua puluh enam lokasi untuk mengkomunikasikan data dan informasi.

Dalam prakteknya, terdapat tiga level untuk tujuan keamanan yang harus dilewati. Pertama, tiap gudang tersebut dilengkapi fasilitas virtual private network (Gambar 2)). Virtual private network (VPN) adalah jaringan pribadi (bukan untuk akses umum) yang menggunakan medium nonpribadi (internet) untuk menghubungkan antar remote-site secara aman. Konsep kerja VPN, pada dasarnya VPN membutuhkan sebuah server yang berfungsi sebagai penghubung antar PC.

\section{Internet VPN}

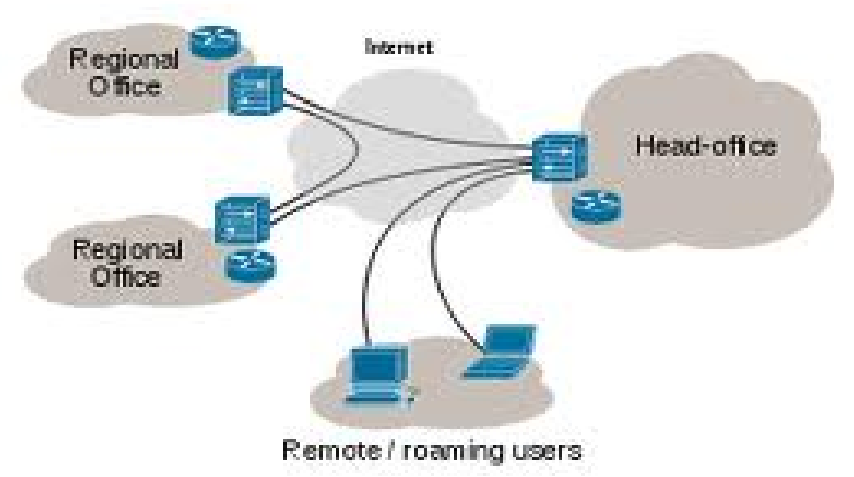

Gambar 2 Jaringan virtual private network (VPN)

Kedua, user yang akan mengakses ke jaringan, harus memasukkan password terlebih dulu untuk masuk ke dalam aplikasi. Ketiga, dalam aplikasi User ID dan password, user akan diminta untuk dimasukkan lagi. User ID dan password-nya.

\section{Hasil Implementasi ERP pada PT Semen Gresik}

Di dalam pertimbangannya melakukan implementasi ERP, PT Semen Gresik bukan hanya mengutamakan kepentingan sektoral yang hanya sekedar untuk fungsi tertentu atau suatu unit bisnis tertentu, apalagi hanya semata-mata untuk program teknologi informasi semata. Berikut adalah hasil implementasi ERP pada PT Semen Gresik: 
Pertama, proses distribusi yang berlangsung di PT Semen Gresik jauh lebih efisien. Efisiensi proses distribusi dapat dilihat dari kemampuan berbagai distributor di PT Semen Gresik untuk melakukan aktivitas-aktivitas dalam proses distribusi terhadap pemenuhan pemesanan secara cepat dan tepat, karena informasi yang mereka dibutuhkan telah terintegrasi. Dan adanya penyederhanaan proses distribusi yang kompleks sehingga menjadi lebih mudah.

Kedua, berkurangnya keluhan dari para user. Dengan sistem informasi yang terintegrasi, komunikasi data dan informasi yang sering menimbulkan kesalahpahaman dan tidak akurat atau terlambat menjadi lebih cepat, sebab data dapat diperoleh pada satu database yang sama dan real time.

Ketiga, meningkatnya produktivitas user. Melalui implementasi ERP, user dapat melakukan pekerjaan dan tugas mereka dengan nyaman dan tidak rumit, sehingga mereka dapat menyelesaikan satu perkerjaan dengan tepat waktu atau kuramg dari waktu yang telah ditentukan, sehingga mereka dapat mengerjakan tugas lainnya.

Keempat, meningkatnya penjualan semen pada PT Semen Gresik. Dengan mengimplementasikan ERP, PT Semen Gresik dapat memenuhi pemesanan semen dari mitra bisnisnya seperti distributor secara cepat, karena PT Semen Gresik telah memfasilitasi mereka dengan teknologi yang dapat menghubungkan proses-proses mereka lakukan.

Kelima, menciptakan akuntabilitas dan pengendalian yang ketat dalam menjalankan operasi distribusi. Kedua hal ini dapat diwujudkan dengan adanya tiga level keamanan yang dipraktekkan dalam PT Semen Gresik ketika user akan mengakses data pada sistem ERP.

Keenam, manajemen dapat melakukan pengambilan keputusan dengan lebih baik. Dengan sistem informasi yang terintegrasi, laporan dapat dihasilkan dengan tepat waktu, selain itu informasi laporan yang dihasilkan terjamin keakuratannya, sehingga manajemen dapat melakukan pengambilan keputusan yang terbaik.

Berikut ini, beberapa dampak positif dari implementasi ERP pada PT Semen Gresik: (1) menghindari terjadinya duplikasi data dan informasi pada distributor; (2) menghindari terjadinya akses data distribusi oleh pihak yang tidak berwenang; (3) memungkinkan manager untuk tidak hanya mengawasi tapi juga mengatur kegiatan distribusi; (4) manajer dapat memberikan respon yang lebih cepat atau tanggap terhadap terjadinya perubahan dalam sistem distribusi; (5) memperbaiki pengambilan keputusan manajemen di dalam PT Semen Gresik dengan sistem yang secara penuh terintegrasi dalam perusahaan; (6) mempersingkat atau mempermudah proses distribusi yang dijalankan dalam perusahaan sehingga menjadi lebih optimal dari sebelumnya; (7) hubungan departmen satu dengan departmen distribusi di dalam PT Semen Gresik menjadi mudah, sehingga dapat saling berbagi data antar departmen dalam perusahaan; (8) meningkatnya efisiensi distribusi dan produktifitas PT Semen Gresik; (9) monitoring (memantau keadaan perusahaan saat itu) dan forecasting (memprediksikan atau merencanakan apa yang akan dikerjakan nantinya) di dalam perusahaan menjadi lebih baik; (10) meningkatkan layanan terhadap mitra bisnis PT Semen Gresik yaitu para distributor.

Di sisi lain, terdapat beberapa dampak negatif dari implementasi ERP pada PT Semen Gresik, yaitu: (1) keuntungan yang diharapkan dengan penerapan ERP tidak dapat dirasakan dalam waktu yang singkat setelah ERP diimplementasikan, namun perlu waktu yang agak lama setelah implementasi ERP; (2) terbatasnya kemampuan ERP dalam menyesuaikan berbagai kondisi yang mungkin terjadi dalam distribusi yang ada pada PT Semen Gresik; (3) implementasi ERP yang cukup lama pada PT Semen Gresik membuat perusahaan harus mengeluarkan biaya yang cukup banyak mulai dari proses instalasi hingga menjalankan sistem ERP; (4) jika keahlian dan pengalaman dari tim IT sedikit, dukungan teknis yang dibutuhkan dalam implementasi ERP pada PT Semen Gresik dapat 
menyebabkan proses distribusi menjadi buruk; (5) kesulitan user untuk beradaptasi terhadap sistem ERP, sehingga mungkin akan muncul pihak yang menentang perubahan dalam perusahaan.

\section{PENUTUP}

Implementasi ERP pada PT Semen Gresik mampu menghasilkan perbaikan pada proses distribusi yang sangat kompleks, karena tersebar di berbagai daerah di Indonesia menjadi lebih efektif dan efisien. Efektivitas proses distribusi dari hasil implementasi ERP, dapat di lihat pada beberapa dampak yang ditimbulkan bagi PT Semen Gresik seperti meningkatkan layanan terhadap mitra bisnis yaitu salah satunya distributor, memberikan kemampuan pada perusahaan untuk dapat bersaing dengan kompetitor dari bidang bisnis yang sama, memperbaiki pengambilan keputusan manajemen, dan sebagainya.

Sedangkan Efisiensi proses distribusi dari hasil implementasi ERP, dapat dilihat pada beberapa dampak yang ditimbulkan bagi PT Semen Gresik seperti mempersingkat atau mempermudah proses distribusi yang dijalankan dalam perusahaan sehingga menjadi lebih optimal dari sebelumnya, manajer dapat memberikan respon yang lebih cepat atau tanggap terhadap terjadinya perubahan dalam sistem distribusi, dan sebagainya. dapat memberikan banyak keuntungan asalkan mampu diimplementasi dengan baik.

Di sisi lain, implementasi ERP pada PT Semen Gresik juga memberikan efek samping atas perbaikan pada proses distribusi, seperti: (1) modal yang sangat besar sedangkan manfaat keuangan tidak dapat dirasakan tidak dalam waktu dekat; (2) keterbatasan ERP untuk menyesuaikan kondisi yang beragam di dalam proses distribusi; (3) tuntutan untuk merancang proses distribusi yang baru dan seterusnya.

Dari pembahasan yang telah dilakukan, dapat disimpulkan bahwa ada beberapa hal yang perlu menjadi perhatian di dalam menyikapi kedua hal di atas, yaitu PT Semen Gresik perlu merencanakan suatu perubahan proses distribusi secara matang dan baik. Ini memerlukan komitmen penuh ketika memutuskan untuk mengimplementasikan ERP mulai dari level manajemen sampai ke user. Selain itu, PT Semen Gresik harus siap melakukan perubahan pada budaya yang berlangsung di dalam organisasi.

\section{DAFTAR PUSTAKA}

Brady, Joseph A., Monk, Ellen F., Wagner, Bret J. (2001). Concepts in Enterprise Resource Planning. Kentucky: Thomson Learning.

Fiona Fui-Hoon Nah, Xin Tan \& Soon Hing Teh. (2004). An empirical investigation on end-users' acceptance of enterprise systems. Information Resources Management Journal, 17 (3).

Gyampah, Kwasi-Amoako., dan Salam, A. F. (2004). An Extension of the technology acceptance model in an ERP implementation environment. Information \& Management, 41, 731 - 745. 